\title{
A Case of Thanatophoric Dysplasia: The Early Prenatal 2D and 3D Sonographic Findings and Molecular Confirmation of Diagnosis
}

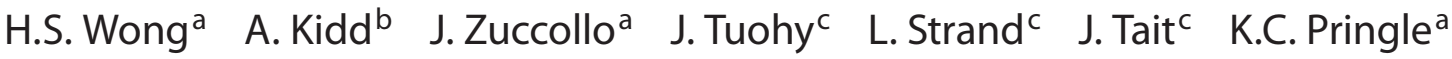 \\ a Department of Obstetrics and Gynaecology, Wellington School of Medicine and Health Sciences, \\ University of Otago, ${ }^{b}$ Central and Southern Regional Genetics Service, and 'Women's Health Service, \\ Capital and Coast District Health Board, Wellington, New Zealand
}

\section{Key Words}

Thanatophoric dysplasia $\cdot$ Skeletal dysplasia $\cdot$ Nuchal translucency · FGFR 3 gene

\begin{abstract}
Objective: To present the early 2D and 3D ultrasound findings and the molecular confirmation in a case of thanatophoric dysplasia. Methods: On ultrasound examination, there was frontal bossing, increased nuchal translucency and short limbs at 12 weeks' gestation and a small thorax and short and bowed long bones on 3D at 16 weeks. Amniocentesis and DNA analysis confirmed the mutation of FGFR3 gene indicating thanatophoric dysplasia. Results: After medical termination of pregnancy, the postmortem X-ray and pathology examination findings were consistent with the diagnosis. Conclusion: 3D anatomy scan and molecular confirmation may be helpful in early diagnosis and genetic counseling of thanatophoric dysplasia.
\end{abstract}

Copyright $\odot 2008$ S. Karger AG, Basel

\section{Case Report}

The patient was 41 years old, G3 P2, referred for nuchal translucency screening. There was no past or family history of congenital abnormalities. Ultrasound examination with ATL
HDI5000 and iU22 (Philips, Bothell, Wash., USA) showed an increased nuchal translucency of $6.5 \mathrm{~mm}$ (fig. 1a) and short fetal limbs (fig. 1b) at 12 weeks' gestation. A chorionic villus biopsy was performed and yielded a normal karyotype. Examination at 16 weeks' gestation showed bilateral neck cysts, head size at the mean for gestation, and short and bowed long bones of normal density (length of long bones $<5$ th centile) on 2D and 3D ultrasound (fig. 2, 3). Although the fetal chest appeared small (fig. 4), the thoracic circumference (TC) was at the 25 th centile, within the normal limits for gestation [1]. However, the TC/AC (abdominal circumference) ratio of 0.73 and femur length/AC ratio of 0.11 were suggestive of lethal skeletal dysplasia [2]. Amniocentesis was subsequently performed since the remaining material from chorionic villus culture was insufficient for further analysis. Three regions of the fibroblast growth factor receptor 3 (FGFR3) gene were amplified using polymerase chain reaction and analyzed by DNA sequencing. It showed that the fetus was heterozygous for an $A \rightarrow G$ transition in the second nucleotide of codon 373 (TAT $\rightarrow \mathrm{TGT}$ ), resulting in Tyr373Cys, consistent with the diagnosis of thanatophoric dysplasia type 1 [3-7]. Termination of pregnancy was requested and performed medically with oral mifepristone and misoprostol. The findings on macroscopic examination (fig. 5a) and babygram (fig. 5b) confirmed the diagnosis, including small chest, flaring of the lower ribs over the protuberant abdomen, marked shortening and bowing of the limbs, femora of 'telephone receiver' outline, platyspondyly of the spine, and normal bone mineralization [7]. Dissection of the fetus was refused by the couple.

\section{KARGER}

Fax +41613061234 E-Mail karger@karger.ch www.karger.com
(C) 2008 S. Karger AG, Basel

$1015-3837 / 08 / 0241-0071 \$ 24.50 / 0$

Accessible online at:

www.karger.com/fdt
Dr. H.S. Wong

Department of Obstetrics and Gynaecology

School of Medicine and Health Sciences, University of Otago, Wellington

PO Box 7343, Wellington South (New Zealand)

Tel. +64 4385 5999, Fax +64 4385 5943, E-Mail hongsoo.wong@otago.ac.nz 

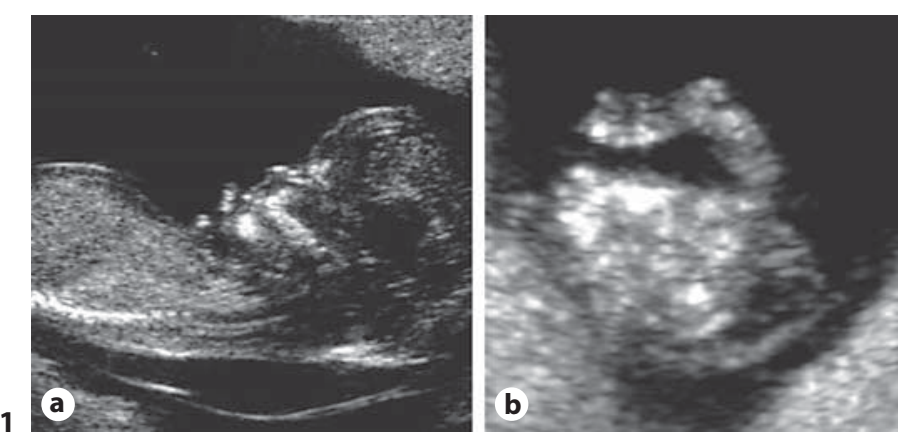

2
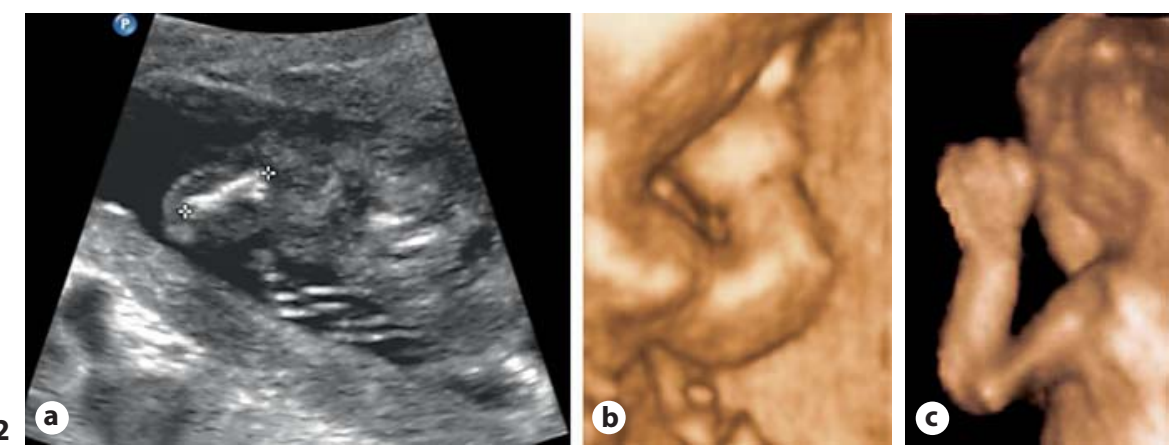

Fig. 1. On transabdominal scan at 12 weeks' gestation, the fetus has increased nuchal translucency, frontal bossing (a) and short upper limb (b).

Fig. 2. At 16 weeks' gestation, micromelia of fetal upper limbs is evident and the humerus appears short and bowed on 2D (a) and $3 \mathrm{D}$ ultrasound (b) compared with a fetus with normal upper limbs of the same gestation (c).

Fig. 3. The fetal femora appear short and bowed (a) compared with those from a fetus with normal limbs at the same gestational age (b) on 3D ultrasound. Arrow = femur, arrowhead = ilium.

Fig. 4. The fetal rib cage appears small (a) compared with the normal rib cage in a fetus of the same gestational age (b).

Fig. 5. On macroscopic examination (a), the fetus was noted to have a small chest, flaring of the lower ribs over the protuberant abdomen, marked shortening and bowing of the limbs. On babygram (b), the bones were of normal mineralization but the femora were of 'telephone receiver' outline and there was platyspondyly of the spine.
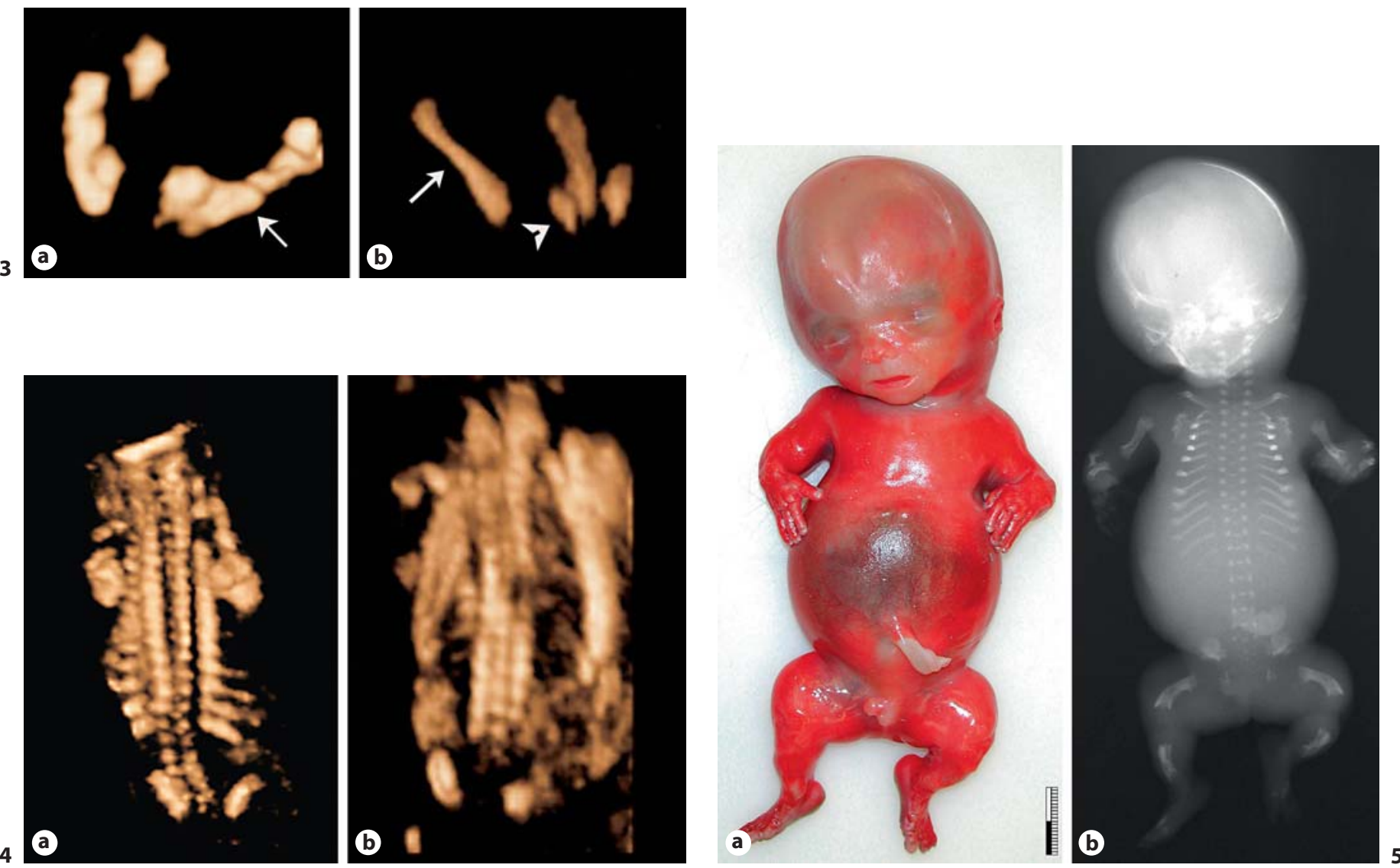


\section{Discussion}

Thanatophotic dysplasia is one of the commonest lethal skeletal dysplasias and occurs at a rate of between $1: 20,000$ and 1:42,221 births [8]. Although the antenatal prediction of lethality in skeletal dysplasia is highly accurate with ultrasound examination, the specific antenatal diagnosis is often difficult and accurate in only about one to two thirds of the cases [9-11]. In a multicenter study, it was reported that the quantification of shortening of femur length might be useful in distinguishing among the common skeletal dysplasias. However, there was considerable overlap in the measurement ranges of the various types of skeletal dysplasia [12].

Prenatal diagnosis of thanatophoric dysplasia presenting in the first trimester has been reported [13-15] and increased nuchal translucency was noted in some of these cases $[14,15]$. However, definitive diagnosis in these cases was made in the early second trimester either pathologically [13] or molecularly $[14,15]$. In the present case, increased nuchal translucency, frontal bossing and short limbs were noticeable at 12 weeks' gestation. These are suggestive, though not diagnostic, of skeletal dysplasia in the presence of normal fetal karyotype. The bony sonographic features (the small rib cage and the abnormal limb bones) were more prominent at 16 weeks' gestation, especially on 3D ultrasound (fig. 2-4). In the presence of increased nuchal translucency and suspicious ultrasound findings, an early anatomy scan especially utilizing 3D ultrasound and application of molecular testing may be helpful in establishing the diagnosis of skeletal dysplasia. The size of the fetal thorax alone, however, did not indicate the lethality of the condition even on early second trimester ultrasound scan in this case. The 3D ultrasound appearance and the use of parameter ratios facilitated the decision process. Molecular testing provided the conclusive diagnosis leading to the genetic counseling of this patient. Although radiological and pathological confirmation are helpful in the diagnosis of skeletal dysplasia, they are not of prime importance in this case.

\section{References}

1 Chitkara U, Rosenberg J, Chervenak FA, Berkowitz GS, Levine R, Fagerstrom RM, Walker B, Berkowitz RL: Prenatal sonographic assessment of the fetal thorax: normal values. Am J Obstet Gynecol 1987;156: 1069-1074.

-2 Parilla BV, Leeth EA, Kambich MP, Chilis P, MacGregor SN: Antenatal detection of skeletal dysplasias. J Ultrasound Med 2003;22: 255-258.

- 3 Rousseau F, el Ghouzzi V, Delezoide AL, Legeai-Mallet L, Le Merrer M, Munnich A, Bonaventure J: Missense FGFR3 mutations create cysteine residues in thanatophoric dwarfism type 1 (TD1). Hum Mol Genet 1996;5:509-512.

-4 Reardon W: Skeletal dysplasias detectable by DNA analysis. Prenat Diagn 1996;16:12211236.

5 Anonymous: International Nomenclature and Classification of the Osteochondrodysplasias (1997). International Working Group on Constitutional Diseases of Bone. Am J Med Genet 1998;79:376-382.
6 Cohen MM Jr: Some chondrodysplasias with short limbs: molecular perspectives. Am J Med Genet 2002;112:304-313.

7 Wilcox WR, Tavormina PL, Krakow D, Kitoh H, Lachman RS, Wasmuth JJ, Thompson LM, Rimoin DL: Molecular, radiologic, and histopathologic correlations in thanatophoric dysplasia. Am J Med Genet 1998;78: 274-281.

8 Online Mendelian Inheritance in Man: http://www.ncbi.nlm.nih.gov/entrez/dispomim.cgi?id=187600 [accessed February 18, 2007].

-9 Tretter AE, Saunders RC, Meyers CM, Dungan JS, Grumbach K, Sun CC, Campbell AB, Wulfsberg EA: Antenatal diagnosis of lethal skeletal dysplasias. Am J Med Genet 1998;75: 518-522.

10 Gaffney G, Manning N, Boyd PA, Rai V, Gould S, Chamberlain P: Prenatal sonographic diagnosis of skeletal dysplasias - a report of the diagnostic and prognostic accuracy in 35 cases. Prenat Diagn 1998; 18: 357-362.
11 Doray B, Favre R, Viville B, Langer B, Dreyfus M, Stoll C: Prenatal sonographic diagnosis of skeletal dysplasias. A report of 47 cases. Ann Genet 2000;43:163-169.

12 Goncalves L, Jeanty P: Fetal biometry of skeletal dysplasias: a multicentric study. J Ultrasound Med 1994;13:767-775.

13 Benacerraf BR, Lister JE, DuPonte BL: Firsttrimester diagnosis of fetal abnormalities. A report of three cases. J Reprod Med 1988;33: 777-780.

14 Ferreira A, Matias A, Brandao O, Montenegro N: Nuchal translucency and ductus venosus blood flow as early sonographic markers of thanatophoric dysplasia. A case report. Fetal Diagn Ther 2004;19:241-245.

15 De Biasio P, Ichim IB, Scarso E, Baldi M, Barban A, Venturini PL: Thanatophoric dysplasia type 1 presenting with increased nuchal translucency in the first trimester. Prenat Diagn 2005;25:426-428. 